\title{
Greenhouse gas fluxes in a drained peatland forest during spring frost-thaw event
}

\author{
M. K. Pihlatie ${ }^{1}$, R. Kiese ${ }^{2}$, N. Brüggemann ${ }^{2}$, K. Butterbach-Bahl ${ }^{2}$, A.-J. Kieloaho ${ }^{1}$, T. Laurila ${ }^{3}$, A. Lohila ${ }^{3}$, \\ I. Mammarella ${ }^{1}$, K. Minkkinen ${ }^{4}$, T. Penttilä ${ }^{5}$, J. Schönborn ${ }^{2,6}$, and T. Vesala ${ }^{1}$ \\ ${ }^{1}$ Department of Physics, University of Helsinki, P. O. Box 48, University of Helsinki, 00014, Helsinki, Finland \\ ${ }^{2}$ Institute of Meteorology and Climate Research, Atmospheric Environmental Research (IMK-IFU), Karlsruhe Institute of \\ Technology, Garmisch-Partenkirchen, Germany \\ ${ }^{3}$ Finnish Meteorological Institute, P. O. Box 503, 00101, Helsinki, Finland \\ ${ }^{4}$ Department of Forest Ecology, University of Helsinki, P. O. Box 27, University of Helsinki, 00014, Helsinki, Finland \\ ${ }^{5}$ Finnish Forest Research Institute, Vantaa Unit, Finland \\ ${ }^{6}$ Meteorological Institute, Albert-Ludwigs-University Freiburg, Freiburg, Germany
}

Received: 29 May 2009 - Published in Biogeosciences Discuss.: 23 June 2009

Revised: 8 April 2010 - Accepted: 28 April 2010 - Published: 25 May 2010

\begin{abstract}
Fluxes of greenhouse gases (GHG) carbon dioxide $\left(\mathrm{CO}_{2}\right)$, methane $\left(\mathrm{CH}_{4}\right)$ and nitrous oxide $\left(\mathrm{N}_{2} \mathrm{O}\right)$ were measured during a two month campaign at a drained peatland forest in Finland by the eddy covariance (EC) technique $\left(\mathrm{CO}_{2}\right.$ and $\left.\mathrm{N}_{2} \mathrm{O}\right)$, and automatic and manual chambers $\left(\mathrm{CO}_{2}\right.$, $\mathrm{CH}_{4}$ and $\mathrm{N}_{2} \mathrm{O}$ ). In addition, GHG concentrations and soil parameters (mineral nitrogen, temperature, moisture content) in the peat profile were measured. The aim of the measurement campaign was to quantify the GHG fluxes during freezing and thawing of the top-soil, a time period with potentially high GHG fluxes, and to compare different flux measurement methods. The forest was a net $\mathrm{CO}_{2}$ sink during the two months and the fluxes of $\mathrm{CO}_{2}$ dominated the GHG exchange. The peat soil was a small sink of atmospheric $\mathrm{CH}_{4}$ and a small source of $\mathrm{N}_{2} \mathrm{O}$. Both $\mathrm{CH}_{4}$ oxidation and $\mathrm{N}_{2} \mathrm{O}$ production took place in the top-soil whereas $\mathrm{CH}_{4}$ was produced in the deeper layers of the peat, which were unfrozen throughout the measurement period. During the frost-thaw events of the litter layer distinct peaks in $\mathrm{CO}_{2}$ and $\mathrm{N}_{2} \mathrm{O}$ emissions were observed. The $\mathrm{CO}_{2}$ peak followed tightly the increase in soil temperature, whereas the $\mathrm{N}_{2} \mathrm{O}$ peak occurred with a delay after the thawing of the litter layer. $\mathrm{CH}_{4}$ fluxes
\end{abstract}

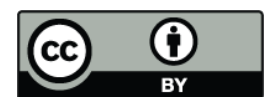

Correspondence to: M. K. Pihlatie (mari.pihlatie@helsinki.fi) did not respond to the thawing of the peat soil. The $\mathrm{CO}_{2}$ and $\mathrm{N}_{2} \mathrm{O}$ emission peaks were not captured by the manual chambers and hence we conclude that high time-resolution measurements with automatic chambers or EC are necessary to quantify fluxes during peak emission periods. Subcanopy EC measurements and chamber-based fluxes of $\mathrm{CO}_{2}$ and $\mathrm{N}_{2} \mathrm{O}$ were comparable, although the fluxes of $\mathrm{N}_{2} \mathrm{O}$ measured by EC were close to the detection limit of the system. We conclude that if fluxes are high enough, i.e. greater than $5-10 \mu \mathrm{g} \mathrm{N} \mathrm{m}{ }^{-2} \mathrm{~h}^{-1}$, the EC method is a good alternative to measure $\mathrm{N}_{2} \mathrm{O}$ and $\mathrm{CO}_{2}$ fluxes at ecosystem scale, thereby minimizing problems with chamber enclosures and spatial representativeness of the measurements.

\section{Introduction}

Drainage of peatlands for forestry has been a common practice in Fennoscandia during the past 100 years. In Finland, more than half of the original peatland area has been drained for forestry or agricultural use since the 1920s (Paavilainen and Päivänen, 1995; Joosten and Claarke, 2002). Drainage lowers the groundwater table and improves the aeration of the peat, which increases the growth of trees. Thereby, drainage also changes greenhouse gas dynamics of the peatland, as a large part of the decomposition of the peat

Published by Copernicus Publications on behalf of the European Geosciences Union. 
switches from anaerobic to aerobic conditions with a shift from methane $\left(\mathrm{CH}_{4}\right)$ to carbon dioxide $\left(\mathrm{CO}_{2}\right)$ as the endproduct of decomposition (Moore and Dalva, 1993; Silvola et al., 1996; Minkkinen et al., 2002; Roulet et al., 1993, Martikainen et al., 1995; Nykänen et al., 1998). Stimulated aerobic decomposition of the peat releases nutrients, especially nitrogen, to the soil, which may lead to elevated emissions of nitrous oxide $\left(\mathrm{N}_{2} \mathrm{O}\right)$ (Martikainen et al., 1993; Silvola et al., 1996; Laine et al., 1996). However, the changes in $\mathrm{N}_{2} \mathrm{O}$ emissions after drainage seem to depend on the fertility of the original peatland, i.e. its nitrogen content or the $\mathrm{C}: \mathrm{N}$ ratio of the peat, and the level of the water table after the drainage (von Arnold et al., 2005a, b).

Drained peatlands which have been used for agriculture first and then planted with trees (afforested peat soils) are strong point sources of $\mathrm{N}_{2} \mathrm{O}$. These $\mathrm{N}_{2} \mathrm{O}$ emissions are of the same order of magnitude as the emissions from drained peatlands which are still used for agriculture (Maljanen et al., 2001; Regina et al., 2004; Mäkiranta et al., 2007). Drained forested peatlands cover 25\% of forest area in Finland making these ecosystems potentially important sources of greenhouse gases. During the last two decades there has been debate whether the drainage of peatlands for forestry turns them from net sinks of carbon into net sources, and whether $\mathrm{N}_{2} \mathrm{O}$ makes up an important part of the total greenhouse gas balance.

Intensive measurements of GHG emissions from drained peatland forests are scarce. Also, comparisons of different measurement techniques in these ecosystems are almost nonexistent. Most of the studies have been conducted with chamber techniques using weekly to monthly measuring intervals. This measurement frequency may severely miss important emission events, so called "hot moments", related especially to $\mathrm{N}_{2} \mathrm{O}$ emissions from soils (see e.g. Matzner and Borken, 2008; Papen and Butterbach-Bahl, 1999), such as frost-thaw periods which could be substantial in boreal environments (see e.g. Koponen et al., 2004, 2006). As a result, calculations of seasonal or annual budgets of greenhouse gases may be biased and potentially underestimated if the frequency of measurements or spatial coverage is not sufficient to cover variations.

We report results of greenhouse gas emissions $\left(\mathrm{CO}_{2}, \mathrm{CH}_{4}\right.$ and $\mathrm{N}_{2} \mathrm{O}$ ) from a drained peatland forest in Kalevansuo, southern Finland. The measurement campaign lasted two months from the end of April until the end of June 2007, and was run under the NitroEurope IP EU-project. The main aim was to quantify the total GHG balance during a potentially high peak season in the spring, when the peat is melting and frost-thaw driven $\mathrm{N}_{2} \mathrm{O}$ fluxes are likely to occur. We measured net $\mathrm{CO}_{2}$ exchange above and below the forest canopy and $\mathrm{N}_{2} \mathrm{O}$ exchange below the forest canopy by the eddy covariance (EC) method and compared these fluxes to soil $\mathrm{CO}_{2}$, $\mathrm{CH}_{4}$, and $\mathrm{N}_{2} \mathrm{O}$ fluxes measured simultaneously with automated and manual chamber techniques.
Our aim was to estimate the net GHG exchange and the importance of different $\mathrm{C}$ and $\mathrm{N}$ flux components on the total GHG balance during the two-month measuring period. We hypothesise that $\mathrm{N}_{2} \mathrm{O}$ is an important component of the ecosystem greenhouse gas exchange due to "hot moment" emissions such as frost-thaw events. Our second aim was to evaluate the suitability of sub-canopy EC-based $\mathrm{N}_{2} \mathrm{O}$ measurements as a sophisticated alternative to traditionally used chamber methods in this environment. The quality control and flux error analysis of the $\mathrm{EC}_{2} \mathrm{O}$ measurements at the site are presented in this issue in Mammarella et al. (2010).

\section{Materials and methods}

\subsection{Site description}

The measurements were conducted at a Kalevansuo drained peatland forest classified as an ombrotrophic dwarf-shrub pine bog. The site is located in southern Finland $\left(60^{\circ} 39^{\prime} \mathrm{N}\right.$, $24^{\circ} 22^{\prime} \mathrm{E}$ ), where the mean annual precipitation is $606 \mathrm{~mm}$ and the mean annual temperature is $4.3^{\circ} \mathrm{C}$. The bog was drained for forestry in 1971 by open, about $1 \mathrm{~m}$ deep ditches dug with approximately $40 \mathrm{~m}$ spacing between the parallel ditches. In 1973 the site was fertilised with phosphorus and potassium, following the guideline practises for drained peatlands. Drainage resulted in a lowered water table down to approx. $40 \mathrm{~cm}$ from the peat surface, and a changed composition of ground vegetation from typical bog vegetation towards more of a forest understorey. However, some features such as the abundance of peatland dwarf shrubs and fairly high coverage of Sphagnum species still distinguish the site from upland forests. Currently the height of the tree stand is $15-18 \mathrm{~m}$, average basal area is $18 \mathrm{~m}^{2} \mathrm{ha}^{-1}$, and average stem densities are 900, 750, and 40 stems per ha for the dominant Scots pine (Pinus sylvestris L.) trees and the smaller understorey downy birch (Betula pubescens) and Norway spruce (Picea abies L.) trees, respectively. The total LAI in the site is approximately $2 \mathrm{~m}^{2} \mathrm{~m}^{-2}$ (Mammarella et al., 2010).

Forest floor vegetation consisted mainly of hummock dwarf shrubs (Vaccinium vitis-idaea, Vaccinium myrtillus, Empetrum nigrum, Vaccinium uliginosum, Ledum palustre and Betula nana), sedges like Eriophorum vaginatum and mosses (Pleurozium schreberi, Dicranum polysetum, Sphagnum russowii, Spagnum capillifolium and Sphagnum angustifolium).

The depth of the well decomposed Sphagnum peat at the site is approximately $2.5 \mathrm{~m}$ with peat a $\mathrm{pH}$ of 5.0 and $\mathrm{C} / \mathrm{N}$ ratio of 41 in the litter layer and 45 in the top $10 \mathrm{~cm}$ of the peat soil.

\subsection{Flux measurements}

Intensive GHG measurements were carried out from 25 April to 27 June 2007 within a homogenous and representative approx. 1 ha plot of the forest (total area of approx. $60 \mathrm{ha}$ ). The 
main measurements included micrometeorological eddy covariance (EC) measurements of $\mathrm{CO}_{2}$ above and below the forest canopy and $\mathrm{N}_{2} \mathrm{O}$ fluxes below the canopy, automated as well as manual chamber-based measurements of $\mathrm{CO}_{2}$, $\mathrm{CH}_{4}$ and $\mathrm{N}_{2} \mathrm{O}$ fluxes. The locations of the different measurement systems are shown in Fig. 1.

The above canopy $\mathrm{EC} \mathrm{CO}_{2}$ flux measurement system $\left(\mathrm{EC}_{\mathrm{above}}\right)$ included a METEK USA-1 ultra sonic anemometer (METEK GmbH, Elmshorn, Germany) mounted on the top of a $21.5 \mathrm{~m}$ telescopic mast and a LI-7000 $\mathrm{CO}_{2} / \mathrm{H}_{2} \mathrm{O}$ analyzer (Li-Cor, Inc., Lincoln, NE, USA) mounted at $6 \mathrm{~m}$ height in the tower. Air was drawn from the proximity of the sonic to the LI-7000 $\mathrm{CO}_{2} / \mathrm{H}_{2} \mathrm{O}$ analyzer using a Bev-ALine IV tubing (Thermoplastic processes, Stirling, NJ) with an inner diameter of $3.1 \mathrm{~mm}$. The storage flux of $\mathrm{CO}_{2}$ was calculated from the concentration data measured at heights of $21.5 \mathrm{~m}$ and $6 \mathrm{~m}$, the latter being measured with a LI- $820 \mathrm{CO}_{2}$ analyzer (Li-Cor Inc., Lincoln, NE, USA). The storage flux was added to the measured net ecosystem exchange (NEE), hereafter NEE referring to the sum of turbulent and storage fluxes. The mast was located in the centre of the measurement site (Fig. 1).

The sub-canopy EC measurements $\left(\mathrm{EC}_{\mathrm{sub}}\right)$ were conducted at $4 \mathrm{~m}$ height. The sub-canopy mast was located approximately $100 \mathrm{~m}$ southwest of the tall mast, and approximately half way between the tall mast and the automatic soil chambers (see Fig. 1). The $\mathrm{CO}_{2}$ fluxes were measured with a Li-7500 Open-Path Infrared $\mathrm{CO}_{2} / \mathrm{H}_{2} \mathrm{O}$ Gas Analyzer (LiCor, Inc., Lincoln, NE, USA) and a CSAT3 Sonic Anemometer (Campbell Scientific Inc., Logan, UT, USA). EC measurements of $\mathrm{N}_{2} \mathrm{O}$ fluxes were conducted at the same mast using the same CSAT3 anemometer and a tunable diode laser spectrometer (TGA-100A, Campbell Scientific Inc., Logan, UT, USA).

Forest floor (soil and ground vegetation) fluxes of $\mathrm{CO}_{2}$, $\mathrm{N}_{2} \mathrm{O}$ and $\mathrm{CH}_{4}$ were measured with the enclosure method using automatic (transparent) and manual (opaque) chambers. The automatic chamber system consisted of a valve-driven sampling system (custom-made by IMK-IFU) for nine soil chambers with dimensions of $50 \times 50 \times 15 \mathrm{~cm}$ (length $\times$ width $\times$ height). The automatic chambers were located approx. $170 \mathrm{~m}$ southwest of the tall EC mast, and approx. $100 \mathrm{~m}$ southwest from the sub-canopy EC mast (Fig. 1). The chambers were connected to a gas chromatograph (SRI Instruments, Torrance, CA, USA) equipped with an electron capture detector (ECD) for $\mathrm{N}_{2} \mathrm{O}$ and a flame ionization detector (FID) for $\mathrm{CH}_{4}$, and a GMD20D infrared $\mathrm{CO}_{2}$ analyzer (Vaisala, Vantaa, Finland). The nine chambers were split into 3 sets of 3 chambers. One measurement cycle included closures of 3 chambers and a simultaneous calibration with a reference gas. Each chamber was closed for $48 \mathrm{~min}$, and the mean sampling intervals were $6,18,30$, and 42 min after the closure. The measurement system is described in more detail in Kiese and Butterbach-Bahl (2002) and Werner et al. (2007). The vegetation inside the automatic chambers was

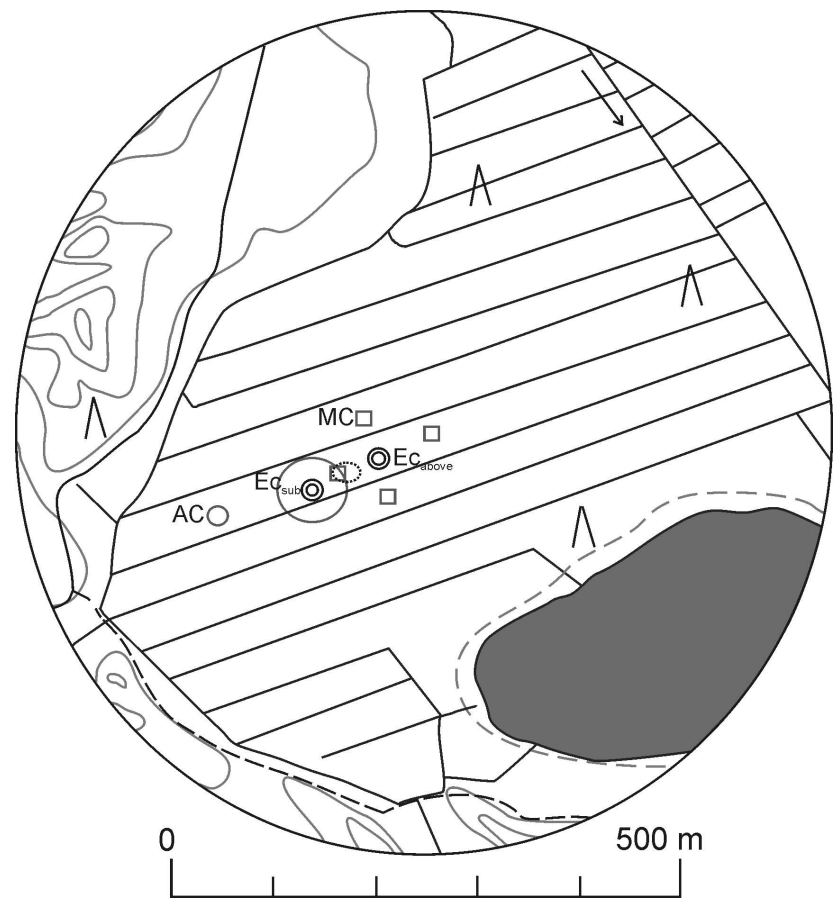

Fig. 1. Map of the measurement site showing the locations of above canopy eddy covariance (EC) mast (ECabove), sub-canopy EC mast (ECsub), manual chambers (MC, square) and automatic chambers (AC, circle). Dotted line next to one of the manual chamber groups show the place of soil gas concentration pits, and grey line around the sub-canopy EC mast show the footprint area from which $85 \%$ (at $30 \mathrm{~m}$ ) of the sub-canopy $\mathrm{N}_{2} \mathrm{O}$ fluxes originate (see Mammarella et al., 2010).

similar than in the peatland generally, however, tall dwarf shrubs were not present. Detailed vegetation survey was not conducted for the automatic chambers.

Manual chamber measurements were conducted once a week during April to June 2007, and fortnightly during July to September 2007. In total 16 circular metal collars were located in groups of four approx. 30-60 m from the tall EC mast in the four main directions, and $10-150 \mathrm{~m}$ north-east from the sub-canopy EC mast (Fig. 1). The collars were installed in 2004 at soil depth of $3-5 \mathrm{~cm}$, on top of the root layer. During chamber measurements, a $30 \mathrm{~cm}$ high circular metal chamber was placed on the collar. Volume of the chamber was approx. $27 \mathrm{~L}$. Air inside the chamber was mixed with a fan, and the temperature inside the chamber was monitored with a thermometer in order to correct the fluxes. Gas samples $(100 \mathrm{ml})$ were collected with a syringe at 2, 15, 25 and $35 \mathrm{~min}$ intervals and transferred immediately into 12 -ml glass vials (Labco Exetainer ${ }^{\circledR}$, Labco Limited, Buckinghamshire, UK). Ninety $\mathrm{ml}$ of the gas sample was used to flush the air in the vial with two needles. The rest $10 \mathrm{ml}$ of the gas sample was used to over-pressurize the vial after removing the flushing needle. Gas samples were analyzed within one week for $\mathrm{N}_{2} \mathrm{O}$ and $\mathrm{CH}_{4}$ by a 
gas chromatograph (Agilent 6890 GC, Agilent Technologies Finland, Espoo, Finland) equipped with an ECD for $\mathrm{N}_{2} \mathrm{O}$ and an FID for $\mathrm{CH}_{4}$.

\subsection{Soil measurements}

Concentrations of $\mathrm{N}_{2} \mathrm{O}$ and $\mathrm{CH}_{4}$ in the peat profile were measured at two pits located approximately $40 \mathrm{~m}$ southwest of the above-canopy EC mast. The concentrations were measured in the peat at $5 \mathrm{~cm}, 22$ and $45 \mathrm{~cm}$ below the litter layer. Gas collector cups were $100 \mathrm{ml}$ in volume and made of stainless steel. The cups were installed horizontally approx. $20 \mathrm{~cm}$ apart from each other, upside down with an open end at the bottom in the soil and connected to the atmosphere via a $1 / 8^{\prime \prime}$ stainless steel tube. Gas samples were collected weekly during April to June from the depths 5 and $25 \mathrm{~cm}$ and fortnightly during July to September from all depths (5, 22 and $45 \mathrm{~cm}$ ). At the time of gas sampling, the $5-10 \mathrm{ml}$ gas volume inside the tubing was discarded after which a $100 \mathrm{ml}$ gas sample was taken and transferred into 12-ml glass vials as described above. When a gas collector was below the groundwater table, a water sample of $50 \mathrm{ml}$ was taken with the syringe. Then the gas dissolved in the water was equilibrated with $50 \mathrm{ml}$ of ambient air by shaking the syringe rigorously for $10 \mathrm{~min}$. After shaking, $20 \mathrm{ml}$ of the gas sample was injected into a pre-evacuated $12-\mathrm{ml}$ glass vial.

Soil temperature and volumetric water contents were measured adjacent to the automatic chambers in the litter layer and at 5 and $10 \mathrm{~cm}$ depths of the peat (Trime ${ }^{\circledR}$ TDR IMKO and Pt-100, IMKO GmbH, Ettlingen, Germany). In addition, soil temperatures in the litter layer, and at 5 and $30 \mathrm{~cm}$ depths of the peat were measured close to the tall EC mast by FMI (Finnish Meteorogical Institute). The variation of the ground water level near the main EC mast was monitored by a PDCR 1830 level pressure sensor (Druck Inc., New Fairfield, CT, USA).

Soil ammonium $\left(\mathrm{NH}_{4}-\mathrm{N}\right)$, nitrate $\left(\mathrm{NO}_{3}-\mathrm{N}\right)$ and total dissolved nitrogen contents were analysed from samples collected weekly during April to June 2007, and monthly during July to September 2007. Soil samples from the litter layer and peat $(0-10 \mathrm{~cm})$ were collected in 5 replicates: four from close vincinity to the manual chambers (4 groups) and one from close vincinity of the automatic chambers. Fresh soil samples were stored at $+4^{\circ} \mathrm{C}$ and extracted with $1 \mathrm{M} \mathrm{KCl}$ the next day after the sampling. The extracts were frozen at $-18^{\circ} \mathrm{C}$ until analysis by a flow injection analyzer (FIA 5012, Tecator) at the Finnish Forest Research Institute. Total carbon and nitrogen contents were analyzed from dried $\left(40^{\circ} \mathrm{C}\right)$ soil samples using a vario MAX CN elemental analyser.

\subsection{Data analysis}

Flux rates of manual and automated chamber measurements were calculated with the following equation

$F_{\mathrm{c}}=\frac{d C}{d t} h$,

where $F_{\mathrm{c}}$ is the flux of the target gas $\left(\mathrm{g} \mathrm{m}^{-2} \mathrm{~s}^{-1}\right), C$ is the gas concentration in the chamber air $\left(\mathrm{g} \mathrm{m}^{-3}\right)$ at standard pressure $(101325 \mathrm{~Pa})$ and temperature measured in the headspace, $t$ is closure time (s) and $h$ the height of the chamber (m). The development of the gas concentration inside the chambers was linear for the majority of the measurements. For the manual chamber data we compared fluxes calculated based on quadratic fit and linear regression. The use of a quadratic fit resulted in up to $30 \%$ higher fluxes of $\mathrm{CH}_{4}$ and $20 \%$ smaller fluxes of $\mathrm{N}_{2} \mathrm{O}$ as compared to the linear regression. Due to only four data points and fluxes close to zero, we considered that the linear regression method was more reliable for this data and hence we calculated all the fluxes by a linear regression analysis $(n=4)$. We filtered out bad quality data by removing data with R2-value 0.7 or less.

EC fluxes were calculated as $30 \mathrm{~min}$ average covariances between the scalars $\left(\mathrm{CO}_{2}\right.$ and $\left.\mathrm{N}_{2} \mathrm{O}\right)$ concentration and the vertical wind velocity according to the commonly accepted procedures (Aubinet et al., 2000). The above canopy EC data acquisition was done with a modified version of a program by McMillen (1986). Coordinate rotation and data detrending by an autoregressive running-mean filter with a 200 -s time constant were performed according to McMillen (1988). The lag between the time series resulting from the transport through the inlet tube was taken into account in the on-line calculation. An air density correction related to the sensible heat flux is not necessary, but the corresponding correction related to the latent heat flux was made (Webb et al., 1980). Corrections for the systematic high-frequency flux loss owing to the imperfect properties and setup of the sensors were carried out off-line using transfer functions with empiricallydetermined time constants. The data processing procedures have been presented in more detail by Lohila et al. (2007) and Aurela et al. (2009).

The sub-canopy fluxes were calculated using software developed by the Micrometeorology group at the University of Helsinki, Department of Physics. The software is routinely used for post-processing EC data measured in several permanent sites and field campaigns. It contains all the update methods and corrections according to the Euroflux methodology (Aubinet et al., 2000; Lee et al., 2004). For the present study, the software was slightly modified in order to handle with the laser data, as reported by Mammarella et al. (2010). All signals were detrended for removing the average values and trends. A simple linear detrending procedure was used for calculating the $\mathrm{CO}_{2}$ flux. The $\mathrm{N}_{2} \mathrm{O}$ signal measured by the TDL gas analyzer was characterized by stronger trends, caused mainly by instrumental drift, which can give an extra 
contribution to the estimated flux in the case that the fluctuations of the concentration are correlated with the fluctuations of the vertical wind velocity. In order to remove the instrumental drift effect and to reduce the random flux variability, a running mean filter (McMillen, 1988) was performed prior to calculation of the $\mathrm{N}_{2} \mathrm{O}$ flux. A more detailed description of the data processing of $\mathrm{N}_{2} \mathrm{O}$ EC signal is given in Mammarella et al. (2010).

A lag-time of $2.3 \mathrm{~s}$ was obtained for the above-canopy $\mathrm{CO}_{2}$ signal, maximizing the cross-covariance function between the $\mathrm{CO}_{2}$ concentration and the vertical wind velocity. The same procedure was applied to the sub-canopy $\mathrm{N}_{2} \mathrm{O}$ signal, but because the $\mathrm{N}_{2} \mathrm{O}$ emissions were very close to detection limit of the system, it was not possible to clearly determine experimentally the $\mathrm{N}_{2} \mathrm{O}$ lag time. Then using a procedure similar to Pihlatie et al. (2005), we used a fix lag time of $1 \mathrm{~s}$. The same value was obtained by using the sample flow and volumes of the inlet tubing and the sample cell, for estimating the theoretical $\mathrm{N}_{2} \mathrm{O}$ lag time. The $\mathrm{CO}_{2}$ flux was corrected for density fluctuations effect (WPL correction; Webb et al., 1980), while such correction was unnecessary for $\mathrm{N}_{2} \mathrm{O}$ fluxes, because of the presence of high flow sample dryer in the system (PD1000 Nafion ${ }^{\circledR}$ dryer, Campbell Scientific, Inc., Logan, UT, USA). Temperature fluctuations do not need to be corrected because they can be assumed to be damped in the sampling tube (Rannik et al., 1997). No Burba correction was used for the eddy covariance data from open path $\mathrm{CO}_{2}$ analyzer even though the correction may slightly increase the flux levels (Burba et al., 2008). The EC fluxes were corrected for the high frequency flux underestimation according to Mammarella et al. (2010). For typical mean wind velocity in the sub-canopy layer, the flux loss was about $5 \%$ and less than $10 \%$ for $\mathrm{CO}_{2}$ and $\mathrm{N}_{2} \mathrm{O}$, respectively.

Statistical tests (paired t-test) for the flux and soil measurement data was done with SPSS statistical program (SPSS Inc., Chicago, IL, USA).

\section{Results}

\subsection{Environmental conditions}

At the start of the measurement campaign part of the peat was still frozen. The air temperatures varied from below $0^{\circ} \mathrm{C}$ in the end of April to a maximum of $27^{\circ} \mathrm{C}$ in the beginning of June (Fig. 2). Prior to the start of the measurement campaign the soil had melted and frozen several times. The first pronounced freeze-thaw cycle was recorded in the end of March, one month prior to the measurement campaign (data not shown). However, as indicated by temperature measurements of air and litter layer, the peat surface layer was still freezing and thawing during the measuring campaign in the end of April (Fig. 2). During the intensive measurement period (25 April-27 June) the soil temperature increased from around $0{ }^{\circ} \mathrm{C}$ up to approx. $16^{\circ} \mathrm{C}$ in the upper part $(5 \mathrm{~cm}$ depth) of the peat soil. Rainfall during April-June was low with low intensities except for two events in mid April and in the end of May, resulting in short increases in the soil water content (Max. 22 vol\%) and water table (see Fig. 2). Despite these short increases, the water table and soil moisture decreased ( $-25 \mathrm{~cm}$ to $-40 \mathrm{~cm} ; 16$ to $<10 \mathrm{vol} \%$ ) during the intensive measurement period.

\subsection{Concentration of soil ammonium, nitrate and total dissolved nitrogen}

Soil nitrate $\left(\mathrm{NO}_{3}^{-}-\mathrm{N}\right)$ concentrations were close to zero throughout the whole measuring period, whereas soil ammonium $\left(\mathrm{NH}_{4}^{+}-\mathrm{N}\right)$ and total nitrogen (tot- $\mathrm{N}$ ) concentrations were elevated at the beginning of the measurement period with a maximum during the frost-thaw event in May, and decreased towards the end of the measuring campaign (Fig. 6). The concentrations of $\mathrm{NO}_{3}^{-}-\mathrm{N}, \mathrm{NH}_{4}^{+}-\mathrm{N}$ and tot- $\mathrm{N}$ were always higher in the litter layer than in the peat at $0-10 \mathrm{~cm}$ depth (data not shown). Total dissolved nitrogen concentrations in the soil varied between $50-230 \mathrm{mg} \mathrm{N} \mathrm{kg}^{-1}$ dry soil, and were approximately one order of magnitude higher than the concentrations of $\mathrm{NH}_{4}^{+}-\mathrm{N}$ in the soil.

\section{$3.3 \mathrm{CO}_{2}$ fluxes}

EC measurements above the forest canopy revealed that the site was on average a net sink for $\mathrm{CO}_{2}$ during the measuring campaign, from late April to late June 2007 (see Fig. 3). The daily net ecosystem exchange (NEE) of $\mathrm{CO}_{2}$ increased from approximately $-0.014 \mathrm{mg} \mathrm{C} \mathrm{m}^{-2} \mathrm{~s}^{-1}$ during April to maximum of $-0.064 \mathrm{mg} \mathrm{C} \mathrm{m}^{-2} \mathrm{~s}^{-1}$ in the middle of June. The drained peatland forest was a weak source of carbon $\left(0.02 \mathrm{mg} \mathrm{C} \mathrm{m}^{-2} \mathrm{~s}^{-1}\right)$ on few rainy days during the measurement period. Overall, the $\mathrm{CO}_{2}$ exchange followed the changes in air and soil temperatures being higher (uptake) in warm and lower (up to emission) in cold days (see Figs. 2 and 3).

In contrast to the net $\mathrm{CO}_{2}$ uptake of the whole forest ecosystem, soil and ground vegetation together turned out to be a source of $\mathrm{CO}_{2}$ to the atmosphere. Both, $\mathrm{CO}_{2}$ fluxes below the forest canopy measured by the EC and by automatic chambers on the soil surface showed an increasing emission trend from April to June (Fig. 3). Forest floor $\mathrm{CO}_{2}$ fluxes (automatic chambers) and sub-canopy fluxes (sub-canopy EC) increased from a minimum of $0.001 \mathrm{mg} \mathrm{C} \mathrm{m}^{-2} \mathrm{~s}^{-1}$ in the end of April to a maximum of $0.013 \mathrm{mg} \mathrm{C} \mathrm{m}^{-2} \mathrm{~s}^{-1}$ and $0.03 \mathrm{mg} \mathrm{C} \mathrm{m}^{-2} \mathrm{~s}^{-1}$, respectively, in the end of May when also soil and air temperatures reached their maximum. In June a decrease in temperature was followed by a decrease in $\mathrm{CO}_{2}$ fluxes, however, this was more pronounced in the sub-canopy EC fluxes. In the end of June forest floor and sub-canopy fluxes leveled around $0.01 \mathrm{mg} \mathrm{C} \mathrm{m}^{-2} \mathrm{~s}^{-1}$, however still following changes in the air and soil temperatures (Figs. 2 and 3). Mean forest floor $\left(0.008 \mathrm{mg} \mathrm{C} \mathrm{m}^{-2} \mathrm{~s}^{-1}\right)$ 


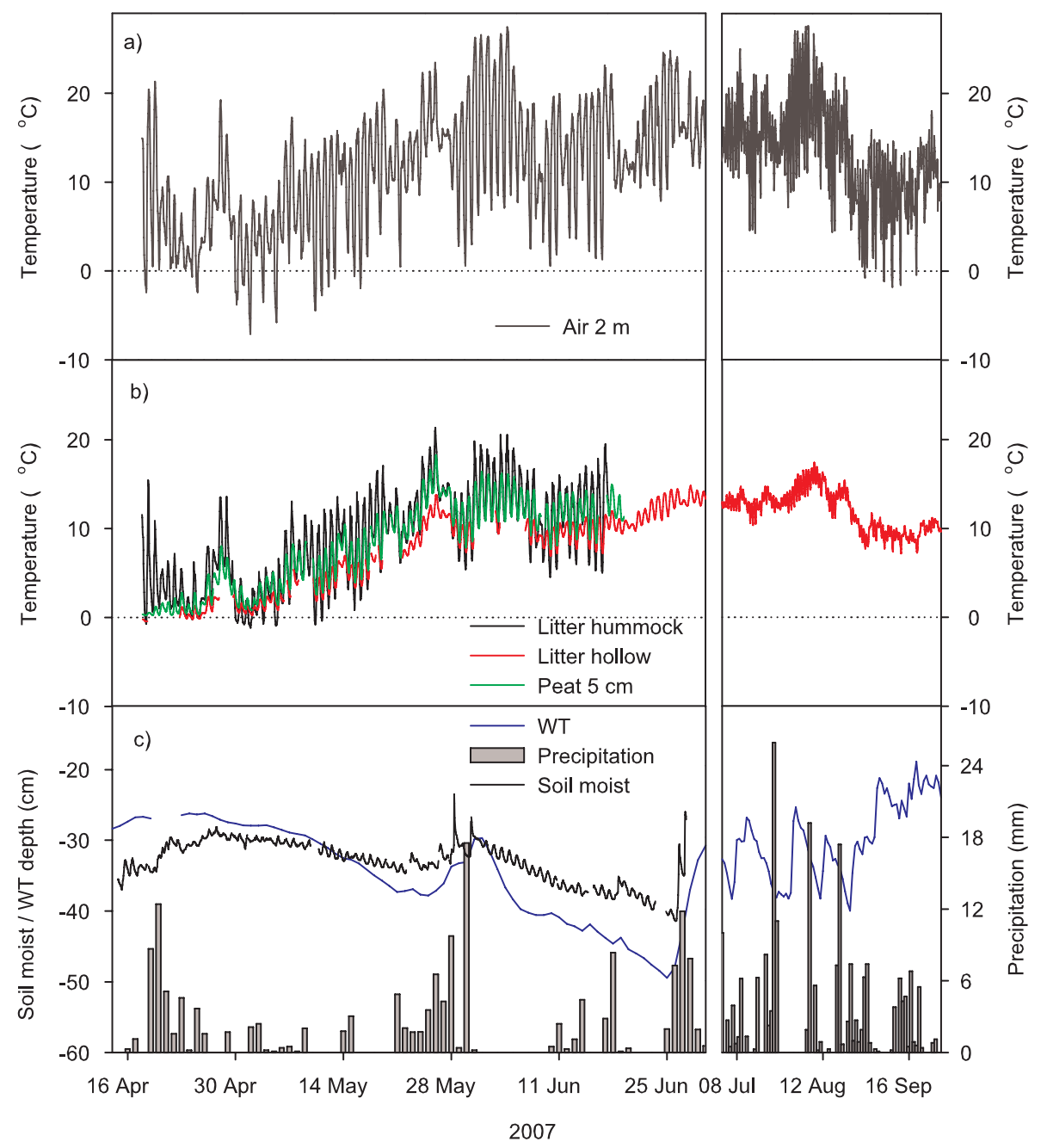

Fig. 2. (a) Air temperature, (b) soil temperatures in litter layer (hummock and hollow) and in peat, and (c) soil moisture (vol/vol), ground water table depth (WT) and precipitation at the drained peatland pine forest during April-September 2007 (intensive measurements 25 April27 June).

and sub-canopy $\mathrm{CO}_{2}$ exchange $\left(0.009 \mathrm{mg} \mathrm{C} \mathrm{m}^{-2} \mathrm{~s}^{-1}\right)$ over the measuring period were almost identical and a paired $\mathrm{t}$ test analysis did not reveal any statistical differences (Table 1). Forest floor $\mathrm{CO}_{2}$ and sub-canopy exchange correlated positively with air and soil temperatures. The soil temperature at $5 \mathrm{~cm}$ depth explained most of the variability in forest floor $\mathrm{CO}_{2}$ flux rates $(r=0.96, p<0.01)$. The correlation was less pronounced for sub-canopy EC based fluxes due to a more scattered temporal emission pattern also reflected in higher values of CV\% (Table 1, Fig. 3). Furthermore, we found a negative correlation of forest floor $\mathrm{CO}_{2}$ fluxes with soil moisture $(-0.60, p<0.01)$ and water table depth $(-0.76$, $p<0.01)$. These correlations were not significant for the ECbased sub-canopy measurements.

The measurement campaign can be divided into two distinct periods: a cold and a warm period. During the cold period (30 April-10 May) the net forest floor $\mathrm{CO}_{2}$ fluxes, the sum of soil respiration and $\mathrm{CO}_{2}$ photosynthesis of ground vegetation, and the $\mathrm{CO}_{2}$ net ecosystem exchange (NEE) above the forest canopy were small (Fig. 4). During the warm period (5 June-15 June) both the net $\mathrm{CO}_{2}$ emissions of the forest floor (Fig. 4c) and the net $\mathrm{CO}_{2}$ uptake of the forest canopy (Fig. 4d) increased. During both cold and warm periods, the sub-canopy $\mathrm{CO}_{2}$ fluxes followed a small but clear diurnal trend when the net $\mathrm{CO}_{2}$ emission decreased during day-time and increased during night-time (Fig. $4 \mathrm{a}$ and c).

The comparison of the mean and median GHG exchange measured by above canopy EC and sub-canopy EC and by automatic forest floor chambers during the entire two-months measurement period is shown in Table 1, and the cumulative fluxes are shown in Table 2. During the period of 25 April21 June the cumulative $\mathrm{CO}_{2}$ fluxes measured by sub-canopy EC $\left(42.5 \mathrm{~g} \mathrm{C} \mathrm{m}^{-2}\right)$ and forest floor chambers $\left(37.7 \mathrm{~g} \mathrm{C} \mathrm{m}^{-2}\right)$ did not statistically differ from each other, and accounted for 
Table 1. Mean and median fluxes of $\mathrm{CO}_{2}, \mathrm{CH}_{4}$ and $\mathrm{N}_{2} \mathrm{O}$ and coefficient of variation $\left(\mathrm{CV} \%{ }^{1}\right)$ measured by eddy covariance, and automatic and manual chambers in Kalevansuo peatland forest during 25 April-27 June 2007. $\mathrm{EC}_{\mathrm{a}}$ and $\mathrm{EC}_{\mathrm{S}}$ stand for eddy covariance above and below the canopy, respectively, and AC and MC stand for automatic and manual chambers, respectively.

\begin{tabular}{lllllllll}
\hline & \multicolumn{3}{c}{$\mathrm{mg} \mathrm{CO}_{2}-\mathrm{C} \mathrm{m}^{-2} \mathrm{~s}^{-1}$} & $\mu \mathrm{CH}_{4}-\mathrm{Cm}^{-2} \mathrm{~h}^{-1}$ & \multicolumn{2}{c}{$\mu \mathrm{g} \mathrm{N}_{2} \mathrm{O}-\mathrm{N} \mathrm{m}^{-2} \mathrm{~h}^{-1}$} \\
\cline { 2 - 8 } & $\mathrm{CO}_{2} \mathrm{EC}_{\mathrm{a}}$ & $\mathrm{CO}_{2} \mathrm{EC}_{\mathrm{s}}$ & $\mathrm{CO}_{2} \_\mathrm{AC}$ & $\mathrm{CH}_{4} \_\mathrm{AC}$ & $\mathrm{CH}_{4} \mathrm{MC}^{2}$ & $\mathrm{~N}_{2} \mathrm{O}_{-} \mathrm{EC}_{\mathrm{s}}$ & $\mathrm{N}_{2} \mathrm{O} \_\mathrm{AC}$ & $\mathrm{N}_{2} \mathrm{O}_{-} \mathrm{MC}^{2}$ \\
\hline Mean $^{3}$ & $-0.031^{\mathrm{a}}$ & $0.009^{\mathrm{b}}$ & $0.008^{\mathrm{b}}$ & $-37.1^{\mathrm{a}}$ & $-18.5^{\mathrm{b}}$ & $3.2^{\mathrm{a}}$ & $4.5^{\mathrm{b}}$ & $6.8^{\mathrm{c}}$ \\
Median & -0.026 & 0.008 & 0.008 & -35.6 & -15.2 & 2.5 & 3.9 & 6.8 \\
$\mathrm{CV} \%$ & 180 & 75.7 & 45.3 & 40.2 & 144 & 123 & 62.3 & 42.8 \\
\hline
\end{tabular}

${ }^{1}$ Coefficient of Variation was calculated as $\mathrm{CV} \%=$ stdev of the flux/mean flux $\times 100$.

2 Measurement period 25 April-18 June 2007.

${ }^{3}$ Different superscripts indicate significant differences between flux rates of one component measured with different methods.

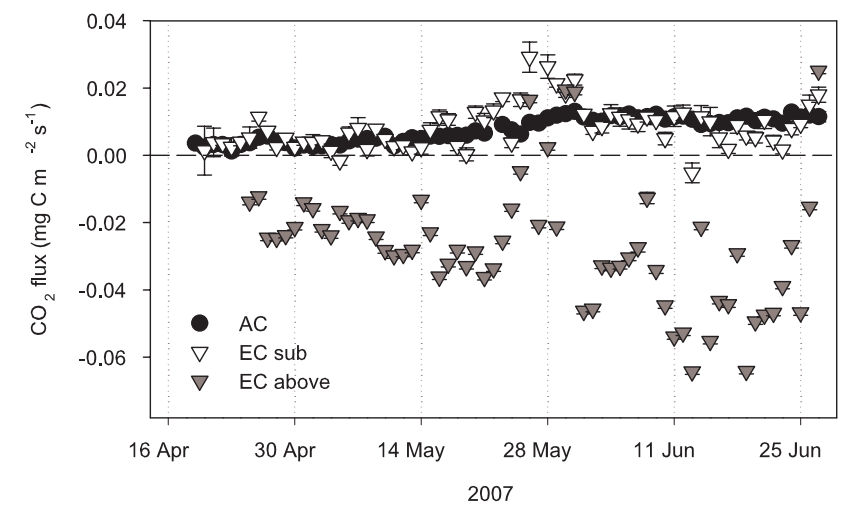

Fig. 3. (a) Daily mean $\mathrm{CO}_{2}$ exchange measured with eddy covariance above the forest canopy (EC above) and inside the canopy (EC sub) and automatic chambers (AC) at the drained peatland pine forest. Error bars stand for standard deviations.

42 and $37 \%$ of the total NEE $\left(-102 \mathrm{~g} \mathrm{C} \mathrm{m}^{-2}\right)$, respectively (Table 2).

\section{$3.4 \mathrm{CH}_{4}$ fluxes}

Kalevansuo peatland forest was a small sink for $\mathrm{CH}_{4}$ during the measurement campaign (Fig. 5a). The $\mathrm{CH}_{4}$ uptake measured with the automatic chambers increased from around $-30 \mu \mathrm{g} \mathrm{C} \mathrm{m}{ }^{-2} \mathrm{~h}^{-1}$ to a approximately of $-60 \mu \mathrm{g} \mathrm{C} \mathrm{m}{ }^{-2} \mathrm{~h}^{-1}$ in June. The $\mathrm{CH}_{4}$ fluxes measured with manual chambers were constantly by at least a factor of two smaller than the $\mathrm{CH}_{4}$ fluxes measured with the automatic chambers (Fig. 5). The fluxes of $\mathrm{CH}_{4}$ were not affected by thawing of the soil but followed more closely the groundwater table and soil moisture content in the peat. $\mathrm{CH}_{4}$ uptake correlated positively with soil water content $(r=0.38, p<0.01)$ and water table depth $(r=0.44, p<0.01)$, and negatively with soil temperatures at $5 \mathrm{~cm}$ and at $30 \mathrm{~cm}$ depth $(r=-0.50, p<0.01$; $r=-0.62, p<0.01)$, respectively, and $\mathrm{CO}_{2}$ fluxes measured by the automatic chambers $(r=-0.50, p<0.01)$.

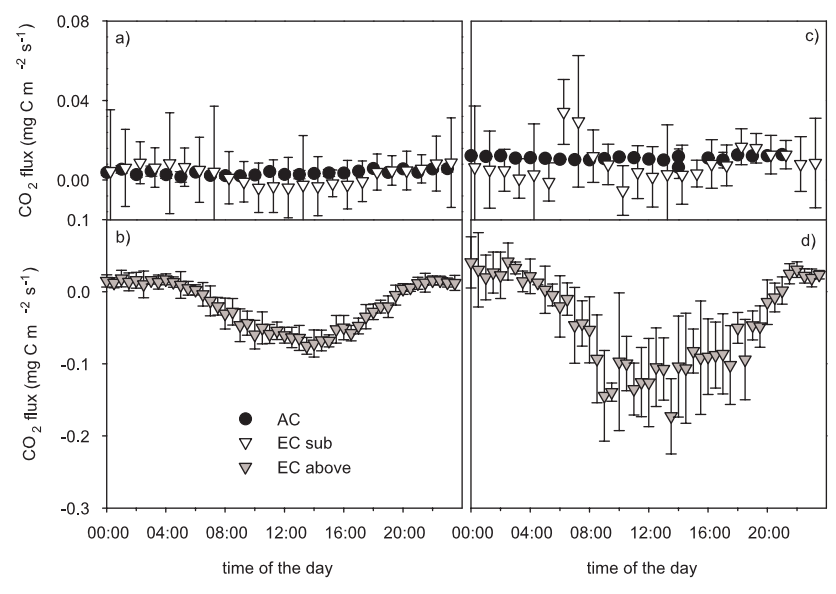

Fig. 4. Daily time course of $\mathrm{CO}_{2}$ fluxes at the drained peatland pine forest measured with automatic chambers (AC) and subcanopy eddy covariance (EC sub) (a), (c) and above canopy eddy covariance (EC above) (b), (d) during a cold period in 30 April10 May 2007 (a), (b) and a warm period in 5-15 June 2007 (c), (d). Dots represent median values for each hour (AC, EC sub) or half hour (EC above) over the 10-day period. Error bars represent standard deviations.

\section{5 $\quad \mathrm{N}_{2} \mathrm{O}$ fluxes}

Kalevansuo drained peatland forest was a small source of $\mathrm{N}_{2} \mathrm{O}$ during the measurement period from April to June 2007. Mean emission rates varied between $3.2 \mu \mathrm{g} \mathrm{N} \mathrm{m}{ }^{-2} \mathrm{~h}^{-1}$ measured by the sub-canopy EC technique, $4.5 \mu \mathrm{g} \mathrm{N} \mathrm{m}^{-2} \mathrm{~h}^{-1}$ by the automatic chambers, and $6.8 \mu \mathrm{g} \mathrm{N} \mathrm{m}^{-2} \mathrm{~h}^{-1}$ by the manual chamber techniques (Fig. 6, Table 1). Independent of the measuring technique $\mathrm{N}_{2} \mathrm{O}$ emissions hardly exceeded $10 \mu \mathrm{g} \mathrm{N} \mathrm{m}^{-2} \mathrm{~h}^{-1}$ except for a short period at the beginning of the measuring campaign when elevated $\mathrm{N}_{2} \mathrm{O}$ emissions could be detected at least with the temporally highly resolved $\mathrm{EC}$ and automatic chamber measurements (see Fig. 6). The elevated $\mathrm{N}_{2} \mathrm{O}$ emissions coinside 
Table 2. Cumulative greenhouse gas $\mathrm{CO}_{2}, \mathrm{CH}_{4}$ and $\mathrm{N}_{2} \mathrm{O}$ fluxes at the Kalevansuo drained peatland forest measured by eddy covariance and automatic chambers during the intensive measurement period 25 April-26 June 2007.

\begin{tabular}{lrrr}
\hline Component & $\begin{array}{r}\text { cumulative flux, } \\
\mathrm{C} \mathrm{m}^{-2}\end{array}$ & $\begin{array}{r}\text { cumulative flux, } \\
\mathrm{g} \mathrm{GHG} \mathrm{m}^{-2}\end{array}$ & $\mathrm{GWR}_{100} \mathrm{CO}_{2}$ eqv. \\
\hline $\mathrm{CO}_{2}-\mathrm{EC}_{\mathrm{a}}$ (NEE) & -102 & -373 & -373 \\
$\mathrm{CO}_{2} \mathrm{EC}_{\mathrm{s}}$ & 42.5 & 156 & 156 \\
$\mathrm{CO}_{2}$ AC & 37.7 & 138 & 138 \\
$\mathrm{CH}_{4} \mathrm{AC}$ & -0.046 & -0.062 & -1.30 \\
$\mathrm{~N}_{2} \mathrm{O} \_\mathrm{AC}$ & 0.006 & 0.009 & 2.77 \\
\hline
\end{tabular}

${ }^{1}$ Measurement period 25 April-21 June 2007.

2 GWP100 refers to Global Warming Potential with a 100-year time horizon.

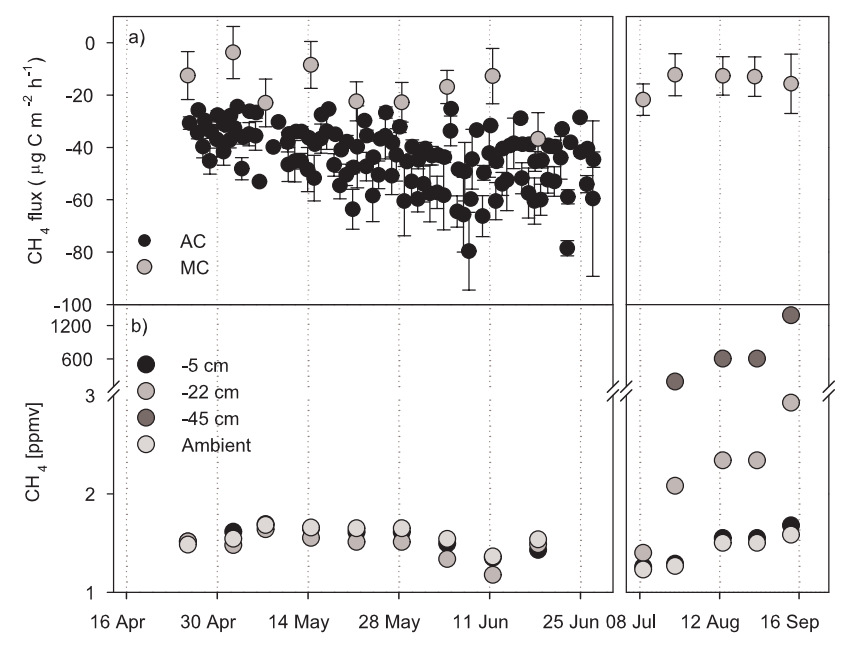

2007

Fig. 5. (a) Daily mean fluxes of $\mathrm{CH}_{4}$ measured with automatic (AC, $n=9$ ) and manual (MC, $n=16$ ) chambers, (b) soil concentrations of $\mathrm{CH}_{4}$ at three depths and in the ambient air measured at the drained peatland. First column of the figures represent the period of intensive measurements, the second shows the data outside the measurement campaign. Error bars stand for standard errors of the mean.

with the coldest period (air temp $<0^{\circ} \mathrm{C}$ ) within the measuring period and a rapid increase in air temperatures up to $15^{\circ} \mathrm{C}$ (Fig. 6). A significant uptake of atmospheric $\mathrm{N}_{2} \mathrm{O}$ was never detected. In general, $\mathrm{N}_{2} \mathrm{O}$ fluxes measured with the EC technique were more variable than chamber based $\mathrm{N}_{2} \mathrm{O}$ fluxes which is indicated by a much higher CV\% of 123 as compared to values of CV\% of 62.3 and 42.8 by the automatic and manual chambers, respectiveley (Table 1). $\mathrm{N}_{2} \mathrm{O}$ emissions measured by the automatic chambers correlated negatively with air temperature $(r=-0.50, p<0.01)$ and soil temperatures in the litter layer, at $5 \mathrm{~cm}$ and at $30 \mathrm{~cm}$ depths $(r=-0.48, p<0.01 ; r=-0.47, p<0.01 ; r=-0.46, p<0.01)$, respectively, soil moisture content $(r=-0.46, p<0.01)$, and

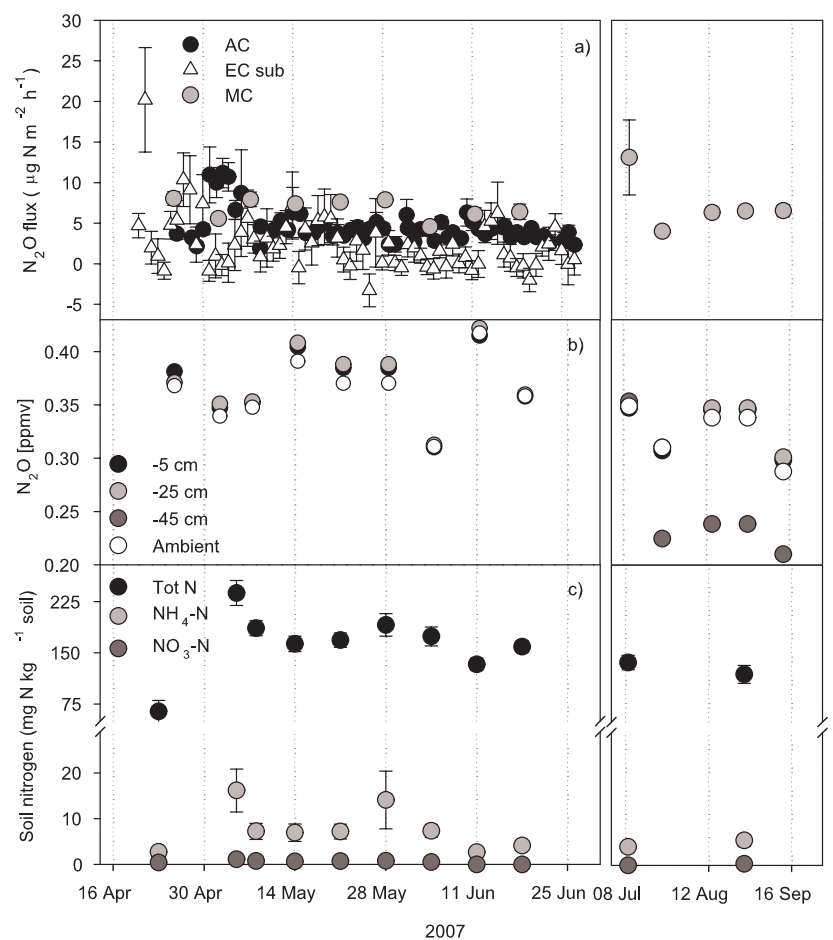

Fig. 6. (a) Mean soil $\mathrm{N}_{2} \mathrm{O}$ fluxes measured with eddy covariance, automatic and manual chambers, (b) soil concentrations of $\mathrm{N}_{2} \mathrm{O}$ at three depths and in the ambient air, and (c) mineral nitrogen and total nitrogen concentrations in the litter layer of the soil during AprilSeptember 2007 at the drained peatland pine forest. First column of the figures represent the period of intensive measurements, the second shows the data outside the measurement campaign. Error bars stand for standard errors of the mean.

$\mathrm{CO}_{2}$ fluxes $(r=-0.48, p<0.01)$. Positive correlations were found with water table depth $(r=0.40, p<0.01)$ and $\mathrm{CH}_{4}$ uptake $(r=0.30, p<0.05)$.

\section{6 $\mathrm{CH}_{4}$ and $\mathrm{N}_{2} \mathrm{O}$ concentration in peat profile}

During the intensive measuring campaign from April to June $2007 \mathrm{CH}_{4}$ and $\mathrm{N}_{2} \mathrm{O}$ concentrations in the peat profile were close to ambient air concentrations of $\sim 1.8 \mathrm{ppmv}$ and $\sim 0.35$ ppmv, respectively (Figs. $5 \mathrm{~b}$ and $6 \mathrm{~b}$ ). In general, during the intensive measurement campaign the $\mathrm{CH}_{4}$ concentrations decreased (i.e. consumption) and $\mathrm{N}_{2} \mathrm{O}$ concentration slightly increased (i.e. production) with peat depth in the topsoil. From July to September the concentrations of $\mathrm{CH}_{4}$ in deeper peat layers (22 and $45 \mathrm{~cm}$ depth) increased markedly. The highest concentration of 1400 ppmv was measured at $45 \mathrm{~cm}$ depth in September. At the same time the $\mathrm{CH}_{4}$ concentrations in the litter layer were close to the ambient air concentrations and the net fluxes measured by manual chambers showed that the soil was still a sink of $\mathrm{CH}_{4}$ (Fig. 5a and $b$ ). 
Nitrous oxide concentrations at $22 \mathrm{~cm}$ depth were most of the time higher than the concentration just below the litter layer at $5 \mathrm{~cm}$ (Fig. 6b). Concentrations at $45 \mathrm{~cm}$ depth measured during July to September varied between 0.210 $0.240 \mathrm{ppmv}$ and were much lower than at 5 or $22 \mathrm{~cm}$ depths and well below the atmospheric concentration.

\section{Discussion}

\section{1 $\mathrm{CO}_{2}$ fluxes}

Eddy covariance (EC) measurements above the forest canopy revealed that the Kalevansuo drained peatland pine forest was a net sink of $\mathrm{CO}_{2}$ during the measuring period from the end of April to the end of June. The measurements below the forest canopy by sub-canopy EC and automatic chambers showed that the forest floor was a net source of $\mathrm{CO}_{2}$, however, only a small part of the net $\mathrm{CO}_{2}$ uptake of the whole forest ecosystem. During few rainy days in the campaign (in total 5 days) the Kalevansuo peatland forest turned from a net sink of carbon to a net source. This finding is in line with the study by Lohila et al. (2007) where they found that an afforested boreal peatland turned from a net sink to a source of carbon during rainy days in the summer. Total NEE at the Kalevansuo drained peatland forest from spring to early summer (25 April-21 June, $-102 \mathrm{~g} \mathrm{C} \mathrm{m}^{-2}$ ) is comparable to NEE values reported from boreal forests growing on mineral or peat soils (Suni et al., 2003; Lohila et al., 2007).

In this study the diurnal variation in the $\mathrm{CO}_{2}$ exchange of the soil and forest floor vegetation was very small measured by the sub-canopy EC and non-existent measured by the automatic soil chambers. Similarly small diurnal variation in the forest floor $\mathrm{CO}_{2}$ exchange of a boreal forest ecosystem has been measured earlier by Launiainen et al. (2005) and Kulmala et al. (2008). However, much stronger diurnal variation in the $\mathrm{CO}_{2}$ exchange of soil and forest floor vegetation has been measured in a temperate forest ecosystem on mineral soil (Subke and Tenhunen, 2004). In our study the lack of diurnal variation in the $\mathrm{CO}_{2}$ exchange of the forest floor may result from (1) a small photosynthetic activity of the forest floor vegetation as compared to the soil and forest floor respiration, or (2) the possibility of high photosynthetic activity during day-time and a simultaneous increase in the soil respiration due to temperature dependency, which then compensates for the photosynthesis. The net forest floor $\mathrm{CO}_{2}$ fluxes measured by sub-canopy EC during April-June period compare well with sub-canopy EC measurements carried out in a boreal pine forest (Launiainen et al., 2005), and chamber based measurements in other drained peatland forests (Martikainen et al., 1995; Alm et al., 1999).

Correlation of forest floor $\mathrm{CO}_{2}$ fluxes was highest with soil temperatures in $5 \mathrm{~cm}$ depth. This shows that rather the top-soil, getting fresh litter input from vegetation, is the major source of $\mathrm{CO}_{2}$ as compared to the peat body itself, thus, stimulated decomposition of the peat due to aeration by drainage has already diminished.

In contrast to $\mathrm{N}_{2} \mathrm{O}$ emissions no increases in $\mathrm{CO}_{2}$ emissions following thawing of the litter layer could be detected. The intermittent increase of $\mathrm{CO}_{2}$ emissions in the end of April can be related to a significant increase in soil and air temperatures, however, in a period when temperatures were never below $0^{\circ} \mathrm{C}$. As the measurements started after the first freeze-thaw cycles, it is unclear whether such freeze-thaw induced $\mathrm{CO}_{2}$ peaks occurred at the site although the absence or less pronounced effect of frost-thaw cycles on in situ $\mathrm{CO}_{2}$ emissions in forest ecosystems is also reported in the review of Matzner and Borken (2008).

\section{2 $\mathrm{CH}_{4}$ fluxes}

Automatic and manual chamber based measurements revealed that the peatland forest was a sink for atmospheric $\mathrm{CH}_{4}$ during the whole measuring period from end of April to end of June 2007. This means that the drainage was deep enough to change the aeration status and, thus, the conditions favourable for methanogenes to those favourable for methanotrophs. The high influence of the water table depth on the $\mathrm{CH}_{4}$ exchange of peatlands has been observed in other studies (Martikainen et al., 1993, 1995) and is further reflected by the significant positive correlation of $\mathrm{CH}_{4}$ uptake rates with changes in water table depth during the observation period. Maximum uptake rates of $>60 \mu \mathrm{g} \mathrm{CH}_{4}-\mathrm{C} \mathrm{m}^{-2} \mathrm{~h}^{-1}$ were significantly higher than observed by Martikainen et al. (1995) for a drainded fen with comparable water table depths. In a large study combining data from drained and undrained peatland forests in Finland Minkkinen et al. (2007) found that in general, undrained sites functioned as $\mathrm{CH}_{4}$ sources whereas drained sites functioned either as $\mathrm{CH}_{4}$ sinks or still as small sources for $\mathrm{CH}_{4}$. In their study the mean $\mathrm{CH}_{4}$ uptake rates varied from 1 up to $90 \mu \mathrm{g} \mathrm{CH}_{4}-\mathrm{C} \mathrm{m}^{-2} \mathrm{~h}^{-1}$. For the Kalevansuo site Minkkinen et al. (2007) reported an annual $\mathrm{CH}_{4}$ uptake of $0.2 \mathrm{~g} \mathrm{C} \mathrm{m}^{-2}$. A simple linear extrapolation from the cumulative flux to a full year resulted in an uptake of $0.09 \mathrm{~g} \mathrm{C} \mathrm{m}^{-2} \mathrm{yr}^{-1}$ for the automatic chambers and $0.06 \mathrm{~g} \mathrm{C} \mathrm{m}^{-2} \mathrm{yr}^{-1}$ for the manual chambers. This indicates that this drained peatland forest is a significant, but slitghtly smaller $\mathrm{CH}_{4}$ sink as compared to boreal forests in general $\left(-0.15 \mathrm{~g} \mathrm{C} \mathrm{m}^{-2} \mathrm{yr}^{-1}\right)$ (Dutaur and Verchot, 2007).

We found that $\mathrm{CH}_{4}$ was produced throughout spring and summer at 22 and $25 \mathrm{~cm}$ depth in the peat profile. At the same time the net flux of $\mathrm{CH}_{4}$ was negative, showing $\mathrm{CH}_{4}$ uptake. This implies that the Kalevansuo site was well drained and the oxic top-layer of the peat was sufficient not only to oxidize the $\mathrm{CH}_{4}$ produced in deeper layers, but also to oxidize additional atmospheric $\mathrm{CH}_{4}$. This observation is in-line with observations at other sites, where also $\mathrm{CH}_{4}$ concentrations well above atmospheric concentrations were detected in deeper soil layers, while soil was still fucntioning as a net sink for armospheric $\mathrm{CH}_{4}$ (Butterbach-Bahl and Papen, 
2002). The concentration of $\mathrm{CH}_{4}$ in the deep soil below the groundwater table $(-45 \mathrm{~cm})$ increased during the summer from July to September indicating an increase in the production of $\mathrm{CH}_{4}$ in the peat profile. Unfortunately there were no $\mathrm{CH}_{4}$ concentration measurements at $-45 \mathrm{~cm}$ depth during April-June and, hence, it is unknown how the concentration developed at that depth during spring and early summer. At the same time the net $\mathrm{CH}_{4}$ fluxes measured with the manual chambers showed nearly constant values during August and September. This reveals that, as the $\mathrm{CH}_{4}$ production in deep soil increases, also the $\mathrm{CH}_{4}$ oxidation rate in the aerobic peat layer increased during the summer.

The $\mathrm{CH}_{4}$ fluxes measured with automatic and manual chambers differed by almost a factor of two. On average the manual chamber measurements resulted in significantly smaller $\mathrm{CH}_{4}$ uptake values as compared to the automatic chamber measurements. The reason for this difference may be the locations of the chambers, as well as in the chamber design. The automatic chambers were located $170 \mathrm{~m}$ southwest of the EC mast, whereas the manual chambers were in all main directions of the mast at approx. 30-60 m distance. Despite this the vegetation around both manual and automated chambers was very similar. The manual chambers were dark, whereas the automatic chambers were transparent. It remains unclear whether ground vegetation influenced the net uptake of atmospheric methane, or whether the vegetation could participate in $\mathrm{CH}_{4}$ production in the presense of light as suggested by Keppler et al. (2006).

When extrapolating the $\mathrm{CH}_{4}$ fluxes measured with the automatic chambers during the two-month measurement period to a full year we get an annual cumulative $\mathrm{CH}_{4}$ flux of $-0.09 \mathrm{~g} \mathrm{C} \mathrm{m}^{-2} \mathrm{yr}^{-1}$, which is half of the annual sink estimate of $-0.2 \mathrm{~g} \mathrm{C} \mathrm{m}^{-2} \mathrm{yr}^{-1}$ for the same site during the years 2004-2005 (Minkkinen et al., 2007). The sink estimates can be considered as being relatively close to each other keeping in mind that we extrapolate measurements from two months of data to a full year.

\section{$4.3 \quad \mathrm{~N}_{2} \mathrm{O}$ fluxes}

In general, the $\mathrm{N}_{2} \mathrm{O}$ emissions from the drained peatland forest were small and not exceeding $10 \mu \mathrm{g} \mathrm{N} \mathrm{m}{ }^{-2} \mathrm{~h}^{-1}$, except for a short period from the end of April to the beginning of May. During this spring-peak period the daily mean $\mathrm{N}_{2} \mathrm{O}$ emissions measured by automatic chambers and sub-canopy EC peaked at approx. 11 and $20 \mu \mathrm{g} \mathrm{N} \mathrm{m}^{-2} \mathrm{~h}^{-1}$, respectively. The peak in the EC measurements occurred approximately one week before the peak observed by the automatic chambers. Overall, these peak emissions occurred during a period when the air and litter layer temperatures fluctuated around zero and when the peat soil was finally fully melting. However, the peak in sub-canopy EC occurred at the same time as the peak in soil temperature and in $\mathrm{CO}_{2}$ fluxes, whereas the peak measured by the automatic chambers occurred with a delay after the increase in soil temperature. This delayed emission peak took place during a period when air and litter layer temperatures again reached zero degrees, a night time minimum of $-6.9^{\circ} \mathrm{C}$ and $-2.2{ }^{\circ} \mathrm{C}$, respectively. In general, we interpreted that the $\mathrm{N}_{2} \mathrm{O}$ emission peaks measured by both measurement techniques were most likely caused by freeze-thaw events in the litter layer. The reason for different timing in these peak events remain unclear and may be explained by different soil conditions around the automatic chambers and the footprint of the sub-canopy eddy system (see Fig. 1). Similar to our measurements, Holst et al. (2008) related elevated springtime $\mathrm{N}_{2} \mathrm{O}$ emissions in a steppe ecosystem to repeated night-to-day freezing-thawing cycles in the uppermost layer of the soil.

Freeze-thaw peaks in $\mathrm{N}_{2} \mathrm{O}$ emissions have been well documented in laboratory and in field studies in boreal region (Koponen et al., 2004, 2006; Öquist et al., 2004; Regina et al., 2004). Still most of the field measurements have been conducted with weekly to fortnightly manual chamber measurements, thus potentially missing or at least underestimating freeze-thaw driven $\mathrm{N}_{2} \mathrm{O}$ pulses (Groffman et al., 2006). Matzner and Borken (2008) concluded in their review that freeze-thaw events have a high potential to cause gaseous $\mathrm{N}$ losses relevant at the annual time scale in all types of ecosystems. The freeze-thaw peaks measured at Kalevansuo peatland forest were relatively small as compared to thawing peaks measured in forest ecosystems in Central Europe experiencing high loads of $\mathrm{N}$ deposition, where freeze-thaw induced $\mathrm{N}_{2} \mathrm{O}$ emissions have been found to contribute up to $73 \%$ to the annual $\mathrm{N}_{2} \mathrm{O}$ emissions (Papen and ButterbachBahl, 1999). As the measured $\mathrm{N}_{2} \mathrm{O}$ peaks at Kalevansuo drained peatland were relatively small the contribution of freezing-thawing induced emissions is most probably insignificant in this drained peatland forest. However, it has to be stressed that we most likely missed some freeze-thaw related $\mathrm{N}_{2} \mathrm{O}$ emission pulses earlier in the season, as it was clear that the soil had been already partly thawing before the measurement campaign started. These emissions could be even higher than those that were measured since the intensity of freeze-thaw induced $\mathrm{N}_{2} \mathrm{O}$ emission has been shown to decrease with time (Holst et al., 2008; Priemé and Christensen, 2001; Papen and Butterbach-Bahl, 1999).

Regarding the mean $\mathrm{N}_{2} \mathrm{O}$ emission rate of 3.2 to $6.8 \mu \mathrm{g} \mathrm{N} \mathrm{m}^{-2} \mathrm{~h}^{-1}$ over the study period similar values have been reported from natural and drained peatlands in Canada and Scandinavia (Martikainen et al., 1993; Regina et al., 1996; Schiller and Hastie, 1996; von Arnold et al., 2005a, b). The low fluxes at the Kalevansuo site can be explained by the high C:N ratio (40-45) of the litter layer and peat, indicating limited amounts of available nitrogen. Klemedtsson et al. (2005) found a strong negative relationship between C: $\mathrm{N}$ ratios and $\mathrm{N}_{2} \mathrm{O}$ emissions from drained forested peatlands mainly in Sweden and Finland. Klemedtsson et al. (2005) used the C:N ratio as a scaling parameter for estimation of the annual source strength for $\mathrm{N}_{2} \mathrm{O}$ (Ernfors et al., 2008). Our annual $\mathrm{N}_{2} \mathrm{O}$ emission rate of $0.39 \mathrm{~kg} \mathrm{~N} \mathrm{ha}^{-1} \mathrm{yr}^{-1}$ 
extrapolated from our two-month measurement period fits well into the relationship found by Klemedtsson et al. (2005). The importance of the soil C:N ratio as an indicator of the nutrient availability, and thus, the risk of potential ecosystem $\mathrm{N}$ losses could also be demonstrated for other ecosystems with low C:N ratios, e.g. nitrate leaching in European forests (MacDonald et al., 2002) or $\mathrm{N}_{2} \mathrm{O}$ emission from tropical forests (Kiese and Butterbach-Bahl, 2002).

Regina et al. (1998) and Pihlatie et al. (2007) found that in nutrient poor peat soils and in upland boreal forest soils $\mathrm{N}_{2} \mathrm{O}$ emissions originate from the litter layer rather than the peat or mineral soil body. In our study, we found that (1) the $\mathrm{N}_{2} \mathrm{O}$ emissions correlated best with the air and litter layer temperature rather than the soil temperatures in deeper soil layers, (2) the concentrations of available nitrogen $\left(\mathrm{NH}_{4}^{+}-\mathrm{N}\right.$, $\mathrm{NO}_{3}^{-}-\mathrm{N}$ and total $\mathrm{N}$ ) in the litter layer were always higher than the concentrations in the peat, and (3) the $\mathrm{C}: \mathrm{N}$ ratio of the litter layer was lower (approx. 40) than the C:N ratio in the peat body (approx. 45). All of these findings suggesting that most of the $\mathrm{N}$ turnover in this peatland forest takes place in the litter layer, and that the $\mathrm{N}_{2} \mathrm{O}$ production is driven by the $\mathrm{N}$ release from the litter layer.

\subsection{Comparison of the eddy covariance and chamber methods}

The eddy covariance (EC) method is still relatively little used in measuring $\mathrm{N}_{2} \mathrm{O}$ fluxes in terrestrial ecosystems (e.g. Wienhold et al., 1994; Christensen et al., 1996; Laville et al., 1997; Wagner-Riddle et al., 1997; Scanlon and Kiely, 2003; Pihlatie et al., 2005; Eugster et al., 2007). Much more data is available on the $\mathrm{EC}$ measurements of $\mathrm{CO}_{2}$ fluxes in forest ecosystems, especially above forest canopies but also in the trunk-space (e.g. Baldocchi, 2003; Subke and Tenhunen, 2004; Launiainen et al., 2005). Among the studies available on the EC based $\mathrm{N}_{2} \mathrm{O}$ studies only few have focused on method comparison between EC and chamber technique (Christensen et al., 1996; Pihlatie et al., 2005).

Despite measuring close to the detection limit of the $\mathrm{N}_{2} \mathrm{O}$ EC system, the EC and chamber methods compared reasonably well with both $\mathrm{N}_{2} \mathrm{O}$ and $\mathrm{CO}_{2}$ fluxes. The difference between the two methods was that the EC fluxes of especially $\mathrm{N}_{2} \mathrm{O}$ were smaller in magnitude and much noisier than the chamber measurements (see also Mammarella et al., 2010). Part of the variability and high noise level of the EC- $\mathrm{N}_{2} \mathrm{O}$ fluxes was due to the fact that the fluxes were low and close to the detection limit of both the chamber and EC measurement systems. The reasons for the remaining noise in the $\mathrm{EC} \mathrm{N}_{2} \mathrm{O}$ measurements are discussed in more detail in Mammarella et al. (2010). Like in many other studies using the EC method for $\mathrm{N}_{2} \mathrm{O}$, we also ended up using daily averages of the $\mathrm{N}_{2} \mathrm{O}$ fluxes. Reasons for doing so were that the fluxes were small and hence the only way to separate the signal out from the noise is averaging between subsequent flux values.

\subsection{Greenhouse gas balance and the effect of freeze-thaw peaks}

During the intensive measurement period from April to June the greenhouse gas (GHG) balance at Kalevansuo drained peatland was driven by $\mathrm{CO}_{2}$ (Table 2), and the fluxes of $\mathrm{CH}_{4}$ and $\mathrm{N}_{2} \mathrm{O}$ contributed only insignificantly to the GHG balance. The measurements of GHG fluxes at the Kalevansuo site fits with the study of Minkkinen et al. (2002) stating that altered exchange rates due to drainage and afforestation have decreased the radiative forcing of peatlands in Finland. The negative radiative forcing was caused by increases in $\mathrm{CO}_{2}$ sequestration in the tree stands and peat soil, decrease in $\mathrm{CH}_{4}$ emissions from peat to the atmosphere and only a small increase in $\mathrm{N}_{2} \mathrm{O}$ emissions. To our knowledge there are no studies monitoring GHG exchange in the years after drainage, hence, high uncertainty is still associated with estimates of GHG exchange and balance of drained peatlands. As Martikainen et al. (1993) pointed out, the enhancement of the $\mathrm{N}_{2} \mathrm{O}$ emission increase after drainage depends mainly on the nutrient status of the virgin peatland, thus, the overall negative contribution of enhanced $\mathrm{N}_{2} \mathrm{O}$ emissions is potentially higher from nutrient-rich peatlands. Furthermore, the contribution of frost-thaw driven $\mathrm{N}_{2} \mathrm{O}$ emissions to the annual emission budget, which could be especially high in the years shortly after drainage is also unclear. Due to the high and short-term variability of fluxes we conclude that rather automatic chamber or EC method than manual chamber based measurements of $\mathrm{N}_{2} \mathrm{O}$ emissions are needed to further improve our scientific understanding in $\mathrm{N}_{2} \mathrm{O}$ exchange of drained peatlands.

\section{Conclusions}

During the two-month measurement period the greenhouse gas (GHG) balance of the drained peatland forest at Kalevansuo was driven by $\mathrm{CO}_{2}$. Fluxes of $\mathrm{CH}_{4}$ and $\mathrm{N}_{2} \mathrm{O}$ contributed only insignificantly to the GHG balance. The drained peatland forest (approx. after 40 years of drainage impact) was not a strong source of $\mathrm{N}_{2} \mathrm{O}$, but freeze-thaw driven $\mathrm{N}_{2} \mathrm{O}$ emissions may contribute substantially to annual $\mathrm{N}_{2} \mathrm{O}$ fluxes. Comparison between automatic and manual chamber methods, and eddy covariance (EC) method showed large differences, particularly with respect to the fluxes of $\mathrm{CH}_{4}$ and $\mathrm{N}_{2} \mathrm{O}$ measured by the automatic and manual chambers. As the chamber method is generally used for estimating annual GHG budgets of different ecosystems, it is crucial to pay attention to the locations and the number of chambers to cover the spatial variability of the site. Due to the combination of low $\mathrm{N}_{2} \mathrm{O}$ emission levels the EC-TDL-based $\mathrm{N}_{2} \mathrm{O}$ flux measurements were highly uncertain, whereas the EC-based $\mathrm{CO}_{2}$ fluxes compared better with the fluxes measured by the automatic chambers. 
Acknowledgements. We wish to thank Georg Willibald from IMKIFU, as well as Joel Greene and Paul Fluckiger from Campbell Scientific for setting up the EC $\mathrm{N}_{2} \mathrm{O}$ system, Sami Haapanala and Rajasekar Ramadas from the University of Helsinki for helping in the field and in the laboratory. Financial support by Nitroeurope IP EU-project, and the Academy of Finland Center of Excellence program (project number 1118615) and post-doctoral program (project number 127756) is gratefully acknowledged.

Edited by: H. Lankreijer

\section{References}

Alm, J., Saarnio, S., Nykänen, H., Silvola, J., and Martikainen, P. J.: Winter $\mathrm{CO}_{2}, \mathrm{CH}_{4}$ and $\mathrm{N}_{2} \mathrm{O}$ fluxes on some natural and drained boreal peatlands, Biogeochemistry, 44, 163-186, 1999.

Aubinet, M., Grelle, A., Ibrom, A., Rannik, Ü., Moncrieff, J., Foken, T., Kowalski, A. S., Martin, P. H., Berbigier, P., Bernhofer, C., Clement, R., Elbers, J., Granier, A., Grunwald, T., Morgenstern, K., Pilegaard, K., Rebmann, C., Snijders, W., Valentini, R., and Vesala, T.: Estimates of the annual net carbon and water exchange of forests: the EUROFLUX methodology, Adv. Ecol. Res., 30, 113-175, 2000.

Aurela, M., Lohila, A., Tuovinen, J.-P., Hatakka, J., Riutta, T., and Laurila, T.: Carbon dioxide exchange on a northern boreal fen, Boreal Environ. Res., 14, 699-710, 2009.

Baldocchi, D. D.: Assessing the eddy covariance technique for evaluating carbon dioxide exchange rate of ecosystems: past, present and future, Global Change Biol., 9, 479-492, 2003.

Burba, G. G., McDermitt, D. K., Grelle, A., Anderson, D. J. and Xu, L.: Addressing the influence of instrument surface heat exchange on the measurements of $\mathrm{CO}_{2}$ flux from open-path gas analyzers, Global Change Biol., 14, 1-23, 2008.

Butterbach-Bahl, K. and Papen, H.: Four years continuous record of $\mathrm{CH}_{4}$-exchange between the atmosphere and untreated and limed soil of a N-saturated spruce and beech forest ecosystem in Germany, Plant Soil, 240, 77-90, 2002.

Christensen, S., Ambus, P., Arah, J. R., Clayton, H., Galle, B., Griffith, D. W. T., Hargreaves, K. J., Klemedtsson, L., Lind, A.M., Maag, M., Scott, A., Skiba, U., Smith, K. A., Welling, M., and Wienhold, F. G.: Nitrous oxide emissions from an agricultural field: comparison between measurements by flux chamber and micrometeorological techniques, Atmos. Environ., 30(24), 4183-4190, 1996.

Dutaur, L. and Verchot, V.: A global inventory of the soil $\mathrm{CH}_{4}$ sink, Global Biogeochem. Cy., 21, GB4013, doi:10.1029/2006GB002734, 2007.

Ernfors, M., von Arnold, K., Stendahl, J., Olsson, M., and Klemedtsson, L.: Nitrous oxide emissions from drained organic forest soils - an up-scaling based on $\mathrm{C}: \mathrm{N}$ ratios, Biogeochemistry, 89, 29-41, 2008.

Eugster, W., Zeyer, K., Zeeman, M., Michna, P., Zingg, A., Buchmann, N., and Emmenegger, L.: Methodical study of nitrous oxide eddy covariance measurements using quantum cascade laser spectrometery over a Swiss forest, Biogeosciences, 4, 927-939, doi:10.5194/bg-4-927-2007, 2007.

Groffman, P. M., Altabet, M. A., Böhlke, J. K., Butterbach-Bahl, K., David, M. B., Firestone, M. K., Giblin, A. E., Kana, T. M., Nielsen, L. P., and Voytek, M. A.: Methods for measuring denitrification: Diverse approaches to a difficult problem, Ecol. Appl., 16, 2091-2122, 2006.

Holst, J., Liu, C., Yao, Z., Brüggemann, N., Zheng, X., Giese, M., and Butterbach-Bahl, K.: Fluxes of nitrous oxide, methane and carbon dioxide during freezing-thawing cycles in an Inner Mongolian steppe, Plant Soil, 308, 105-117, 2008.

Joosten, H. and Claarke, D.: Wise Use of Mires and Peatland, International Mire Conservation Group, Totnes., ISBN 951-97744-83, 2002.

Keppler, F., Hamilton, F. J. T., Braß, M., and Röckmann, T.: Methane emissinos from terrestrial plants under aerobic conditions, Nature, 439, 187-191, 2006.

Kiese, R. and Butterbach-Bahl, K.: $\mathrm{N}_{2} \mathrm{O}$ and $\mathrm{CO}_{2}$ emissions from three different tropical forest sites in the wet tropics of Queensland, Australia, Soil Biol. Biochem., 34, 975-987, 2002.

Klemedtsson, L., von Arnold, K., Weslien, P., and Gundersen, P.: Soil CN ratio as a scalar parameter to predict nitrous oxide emissions, Global Change Biol., 11, 1142-1147, 2005.

Koponen, H. T., Flöjt, L., and Martikainen, P. J.: Nitrous oxide emissions from agricultural soils at low temperatures: a laboratory microcosm study, Soil Biol. Biochem., 36, 757-766, 2004.

Koponen, H. T., Escudé Duran, C., Maljanen, M., Hytönen, J., and Martikainen, P. J.: Temperature responses of $\mathrm{NO}$ and $\mathrm{N}_{2} \mathrm{O}$ emissions from boreal organic soil, Soil Biol. Biochem., 38, 17791787, 2006.

Kulmala, L., Launiainen, S., Pumpanen, J., Lankreijer, H., Lindtroth, A., Hari, P., and Vesala, T.: $\mathrm{H}_{2} \mathrm{O}$ and $\mathrm{CO}_{2}$ fluxes at the floor of a boreal pine forest, Tellus B, 60, 167-178, 2008.

Laine, J., Silvola, J., Tolonen, K., Alm, J., Nykänen, H., Vasander, H., Sallantaus, T., Savolainen, I., Sinisalo, J., and Martikainen, P. J.: Effect of water level drawdown in northern peatlands on the global climatic warming, Ambio, 25, 179-184, 1996.

Launiainen, S., Rinne, J., Pumpanen, J., Kulmala, L., Kolari, P., Keronen, P., Siivola, S., Pohja, T., Hari, P., and Vesala, T.: Eddy covariance measurements of $\mathrm{CO}_{2}$ and sensible and latent heat fluxes during a full year in a boreal pine forest trunk-space, Boreal Environ. Res., 10, 569-588, 2005.

Laville, P., Hénault, C., Renault, P., Cellier, P., Oriol, A., Devis, X., Flura, D., and Germon, J. C.: Field comparison of nitrous oxide emission measurements using micrometeorological and chamber methods, Agronomie, 17, 375-388, 1997.

Lee, X. L., Massman, W., and Law, B.: Handbook of micrometeorology, Kluwer Academic Publisher, Dordrecht, The Netherlands, 2004.

Lohila, A., Laurila, T., Aro, L., Aurela, M., Tuovinen, J.-P., Laine, J., Kolari, P., and Minkkinen, K.: Carbon dioxide exchange above a 30-year-old Scots pine plantation established on organicsoil cropland, Boreal Environ. Res., 12, 141-157, 2007.

MacDonald, J. A., Dise, N. B., Matzner, E., Armbruster, M., Gundersen, P., and Forsius, M.: Nitrogen input together with ecosystem nitrogen enrichment predict nitrate leaching from European forests, Global Change Biol., 8, 1028-1033, 2002.

Mäkiranta, P., Hytönen, J., Aro, L., Maljanen, M., Pihlatie, M., Potila, H., Shurpali, N., Laine, J., Lohila, A., Martikainen, P. J., and Minkkinen, K.: Soil greenhouse gas emissions from afforested organic soil croplands and cutaway peatlands, Boreal Environ. Res., 12, 159-175, 2007.

Maljanen, M., Hytönen, J., and Martikainen, P. J.: Fluxes of $\mathrm{N}_{2} \mathrm{O}$, $\mathrm{CH}_{4}$ and $\mathrm{CO}_{2}$ on afforested boreal agricultural soils, Plant Soil, 
231, 113-121, 2001.

Mammarella, I., Werle, P., Pihlatie, M., Eugster, W., Haapanala, S., Kiese, R., Markkanen, T., Rannik, Ü., and Vesala, T.: A case study of eddy covariance flux of $\mathrm{N}_{2} \mathrm{O}$ measured within forest ecosystems: quality control and flux error analysis, Biogeosciences, 7, 427-440, doi:10.5194/bg-7-427-2010, 2010.

Martikainen, P. J., Nykänen, H., Crill, P., and Silvola, J.: Effect of a lowered water table on nitrous oxide fluxes from northern peatlands, Nature, 366, 51-53, 1993.

Martikainen, P. J., Nykänen, H., Alm, J., and Silvola, J.: Change in fluxes of carbon dioxide, methane and nitrous oxide due to forest drainage of mire sires of different trophy, Plant Soil, 168/169, 571-577, 1995.

Matzner, E. and Borken, W.: Do freeze-thaw events enhance C and $\mathrm{N}$ losses from soils of different ecosystems? A review, Eur. J. Soil Sci., 59(2), 274-284, 2008.

McMillen, R. T.: A BASIC program for eddy correlation in nonsimple terrain, NOAA Tech. Memo. ERL ARL-147, NOAA Environ. Res. Lab., Silver Spring, Md., 1986.

McMillen, R. T.: An eddy correlation technique with extended applicability to non simple terrain, Bound.-Lay. Meteorol., 43, 231-245, 1988.

Minkkinen, K., Korhonen, R., Savolainen, I., and Laine, J.: Carbon balance and radiative forcing of Finnish peatlands 1900-2100 the impact of forestry drainage, Global Change Biol., 8, 785799, 2002

Minkkinen, K., Penttilä, T., and Laine, J.: Tree stand volume as a scalar for methane fluxes in forestry-drained peatlands in Finland, Boreal Environ. Res., 12, 127-132, 2007.

Moore, T. R. and Dalva, M.: The influence of temperature and water table position on carbon dioxide and methane emissions from laboratory columns of peatland soils, J. Soil Sci., 44, 651-664, 1993.

Nykänen, H., Alm, J., Silvola, J., Tolonen, K., and Martikainen, P. J.: Methane fluxes on boreal peatlands of different fertility and the effect of long-term experimental lowering of the water table on flux rates, Global Biogeochem. Cy., 12, 53-69, 1998.

Öquist, M. G., Nilsson, M., Sörensson, F., Kasimir-Klemedtsson, Å., Persson, T., Weslien, P., and Klemedtsson, L.: Nitrous oxide production in a forest soil at low temperatures - processes and environmental controls, FEMS Microbiol. Ecol., 49, 371-378, 2004.

Paavilainen, E. and Päivänen, J.: Peatland Forestry - Ecology and Priciples, Springer, Berlin, 248 p., 1995.

Papen, H. and Butterbach-Bahl, K.: A 3-year continuous record of nitrogen trace gas fluxes from untreated and limed soil of a $\mathrm{N}$-saturated spruce and beech forest ecosystem in Germany 1. $\mathrm{N}_{2} \mathrm{O}$ emissions, J. Geophys. Res., 104(D15), 18487-18503, 1999.

Pihlatie, M., Rinne, J., Ambus, P., Pilegaard, K., Dorsey, J. R., Rannik, Ü., Markkanen, T., Launiainen, S., and Vesala, T.: Nitrous oxide emissions from a beech forest floor measured by eddy covariance and soil enclosure techniques, Biogeosciences, 2, 377387, doi:10.5194/bg-2-377-2005, 2005.

Pihlatie, M., Pumpanen, J., Rinne, J., Ilvesniemi, H., Simojoki, A., Hari, P., and Vesala, T.: Gas concentration driven fluxes of nitrous oxide and carbon dioxide in boreal forest soil, Tellus B, 59, 458-469, 2007.

Priemé, A. and Christensen, S.: Natural perturbations, drying- wetting and freezing-thawing cycles, and the emission of nitrous oxide, carbon dioxide and methane from farmed organic soils, Soil Biol. Biochem., 33, 2083-2091, 2001.

Rannik, Ü, Vesala, T., and Keskinen, R.: Damping of temperature fluctuations in circular tube relevant to the eddy covariance technique, J. Geophys. Res., 102, 12789-12794, 1997.

Regina, K., Nykänen, H., Silvola, J., and Martikainen, P. J.: Fluxes of nitrous oxide from boreal peatlands as affected by peatland type, water table level and nitrification capacity, Biogeochemistry, 35, 401-418, 1996.

Regina, K., Silvola, J., and Martikainen, P.: Mechanisms of $\mathrm{N}_{2} \mathrm{O}$ and NO production in the soil profile of a drained and forested peatland, as studied with acetylene, nitrapyrin and dimethyl ether, Biol. Fert. Soils, 27, 205-210, 1998.

Regina, K., Syväsalo, E., Hannukkala, A., and Esala, M.: Fluxes of $\mathrm{N}_{2} \mathrm{O}$ from farmed peat soils in Finland, Eur. J. Soil Sci., 55, 591-599, 2004.

Roulet, N. T., Ash, R., Quinton, W., and Moore, T.: Methane flux from drained northern peatlands: Effect of a persistent water table lowering on flux, Global Biogeochem. Cy., 7, 749-769, 1993.

Scanlon, T. M. and Kiely, G.: Ecosystem-scale measurements of nitrous oxide fluxes for an intensely grazed, fertilized grassland, Geophys. Res. Lett., 30(16), 1852, doi:10.1029/2003GL017454, 2003.

Schiller, C. L. and Hastie, D. R.: Nitrous oxide and methane fluxes from perturbed and unperturbed boreal forest sites in northern Ontario, J. Geophys. Res., 101(D17), 22767-22774, 1996.

Silvola, J., Alm, J., Ahlholm, U., Nykänen, H., and Martikainen, P. $\mathrm{J} .: \mathrm{CO}_{2}$ fluxes from peat in boreal mires under varying temperature and moisture conditions, J. Ecol., 84, 219-228, 1996.

Subke, J.-A. and Tenhunen, J. D.: Direct measurements of $\mathrm{CO}_{2}$ flux below a spruce forest canopy, Agr. Forest Meteorol., 126, 157168, 2004.

Suni, T., Berninger, F., Markkanen, T., Keronen, P., Rannik, Ü, and Vesala, T.: Interannual variability and timing of growing-season $\mathrm{CO}_{2}$ exchange in a boreal forest, J. Geophys. Res., 108(D9), 4265, doi:10.1029/2002JD002381, 2003.

von Arnold, K., Weslien, P., Nilson, M., Svensson, B. H., and Klemedtsson, L.: Fluxes $\mathrm{CO}_{2}, \mathrm{CH}_{4}$ and $\mathrm{N}_{2} \mathrm{O}$ from drained coniferous forests on organic soils, Forest Ecol. Manag., 210, 239-254, 2005a

von Arnold, K., Nilsson, M., Hånell, B., Weslien, D., and Klemedtsson L.: Fluxes of $\mathrm{CO}_{2}, \mathrm{CH}_{4}$ and $\mathrm{N}_{2} \mathrm{O}$ from drained organic soils in deciduous forests, Soil Biol. Biochem., 37, 1059-1071, $2005 \mathrm{~b}$.

Wagner-Riddle, C., Thurtell, G. W., Kidd, G. K., Beauchamp, E. G., and Sweetman, R.: Estimates of nitrous oxide emissions from agricultural fields over 28 months, Can. J. Soil Sci., 77, 135-144, 1997.

Webb, E., Pearman, G., and Leuning, R.: Correction of flux measurements for density effects due to heat and water vapour transfer, Q. J. Roy. Meteorol. Soc., 106, 85-100, 1980.

Werner, C., Kiese, R., and Butterbach-Bahl, K.: Soil-atmosphere exchange of $\mathrm{N}_{2} \mathrm{O}, \mathrm{CH}_{4}$ and $\mathrm{CO}_{2}$ and controlling environmental factors for tropical rain forest sites in western Kenya, J. Geophys. Res., 112, D03308, doi:10.1029/2006JD007388, 2007.

Wienhold, F. G., Frahm, H., and Harris, G. W.: Measurements of $\mathrm{N}_{2} \mathrm{O}$ fluxes from fertilized grassland using a fast response tunable diode laser spectrometer, J. Geophys. Res., 99(D8), 1655716568, 1994. 